Short Note

\title{
A New Flavonoid Glycoside from Salix denticulata Aerial Parts
}

\author{
Usha Rawat, Sushma Semwal, Deepak Kumar Semwal *, Ruchi Badoni and Amita Bamola \\ Department of Chemistry, H. N. B. Garhwal University, Srinagar-246174, U.K., India \\ * Author to whom correspondence should be addressed; E-Mail: dr_dks.1983@yahoo.co.in.
}

Received: 24 July 2009 / Accepted: 7 September 2009 / Published: 23 September 2009

\begin{abstract}
A new flavonoid glycoside (1) has been isolated from the aerial parts of Salix denticulata (Salicaceae) together with five known compounds, $\beta$-sitosterol, 2,6-dihydroxy4-methoxy acetophenone, eugenol-1-O- $\beta$-D-glucopyranoside, 1-O- $\beta$-D-(3'-benzoyl) salicyl alcohol and luteolin-7-O- $\beta$-D-glucopyranosyl-(1-6)-glucopyranoside. The structure of 1 was elucidated as 2',5-dihydroxy-3'-methoxyflavone-7-O- $\beta$-D-glucopyranoside by means of chemical and spectral data including 2D NMR studies.
\end{abstract}

Keywords: Salix denticulate; Salicaeae; flavonoid glycoside

\section{Introduction}

Salix denticulata which belongs to the Salicaceae family is a deciduous shrub indigenous to Central Himalayas (3000 meter) of India and is well known for its medicinal importance [1]. Previous studies on the plants of this genus led to isolation and elucidation of different compounds such as terpenoids [2], catechins [3], lignans [4], flavones [5,6] and other phenolic compounds [7]. This paper illustrates the isolation and structure revelation of a novel flavonoid glycoside (1) from the aereal parts of S. denticulata with the help of modern spectroscopic methods.

\section{Results and discussion}

Compound 1 was isolated as yellow crystalline solid, m.p. $210-212{ }^{\circ} \mathrm{C}$, deduced molecular formula $\mathrm{C}_{22} \mathrm{H}_{22} \mathrm{O}_{11}$ from its FAB-MS. It gave positive Molisch test, Shinoda test and blue color with $\mathrm{FeCl}_{3}$, characteristic for flavone glycosides. The IR spectrum showed characteristic absorption bands for hydroxy $\left(3350 \mathrm{~cm}^{-1}\right)$ and carbonyl $\left(1460 \mathrm{~cm}^{-1}\right)$ functions. The ${ }^{1} \mathrm{H}$ NMR spectrum showed doublets at $\delta 6.46(J=1.8 \mathrm{~Hz}, \mathrm{H}-6)$ and $\delta 6.76(J=1.8 \mathrm{~Hz}, \mathrm{H}-8)$, indicating a tetrasubstituted aromatic ring. Other 
doublets at $\delta 7.12\left(J=3.4 \mathrm{~Hz}, \mathrm{H}-3\right.$ '), $6.92\left(J=8.4 \mathrm{~Hz}, \mathrm{H}-6^{\prime}\right)$ and $7.44\left(J=3.4,8.4 \mathrm{~Hz}, \mathrm{H}-5{ }^{\prime}\right)$ revealed the trisubstituted aromatic ring. The position of two singlets at $\delta 12.9$ and 9.5 indicated two hydroxy groups, in which former is chelated with a carbonyl function and assigned at position $\mathrm{OH}-5$. A sharp singlet at $\delta 3.61$ correlated to $\mathrm{C}^{\prime}{ }^{\prime}$ ' $(\delta 145.81)$, indicating $\mathrm{OCH}_{3}-4^{\prime}$. A doublet at $\delta 5.08(\mathrm{~J}=7.2 \mathrm{~Hz})$ indicated anomeric signal with other signals in the range of $\delta 3.2-4.6$ for a $\beta$ linked sugar. In the ${ }^{13} \mathrm{C}$ NMR spectrum, the downfield signal at $\delta 181.9$ indicated a carbonyl group. The positions of substituted groups were confirmed by ${ }^{1} \mathrm{H}^{13} \mathrm{C}$ correlation in HMBC (Figure 2) and HSQC. The correlation of H-3' $(\delta$ 7.12) to C-4' $(\delta$ 145.81) and C-5' ( $\delta$ 116.02); H-5' ( $\delta$ 7.44) to C-3' $(\delta 113.5)$, C-4' $(\delta$ 145.81) and C-6' $(\delta$ 119.21) and H-6' $(\delta$ 6.92) to C-1' $(\delta$ 121.42) and C-4' $(\delta$ 145.81) reveled the substitution at $\mathrm{C}-2$ ' $(\mathrm{OH})$ and $\mathrm{C}-4$ ' in ring B. The correlation between the anomeric proton $(\delta 5.09)$ and C-7 ( $\delta$ 162.98) indicated position of sugar at C-7. The sugar was identified as D-glucose by hydrolysis and direct comparison (co-PC) with authentic sugar. The chemical structure of compound 1 is given in Figure 1.

Figure 1. Chemical structure of compound 1.<smiles>COc1ccc(-c2cc(=O)c3c(O)cc(OC4OC(CO)C(O)C(O)C4O)cc3o2)c(O)c1</smiles>

Figure 2. Important HMBC correlations in compound 1.

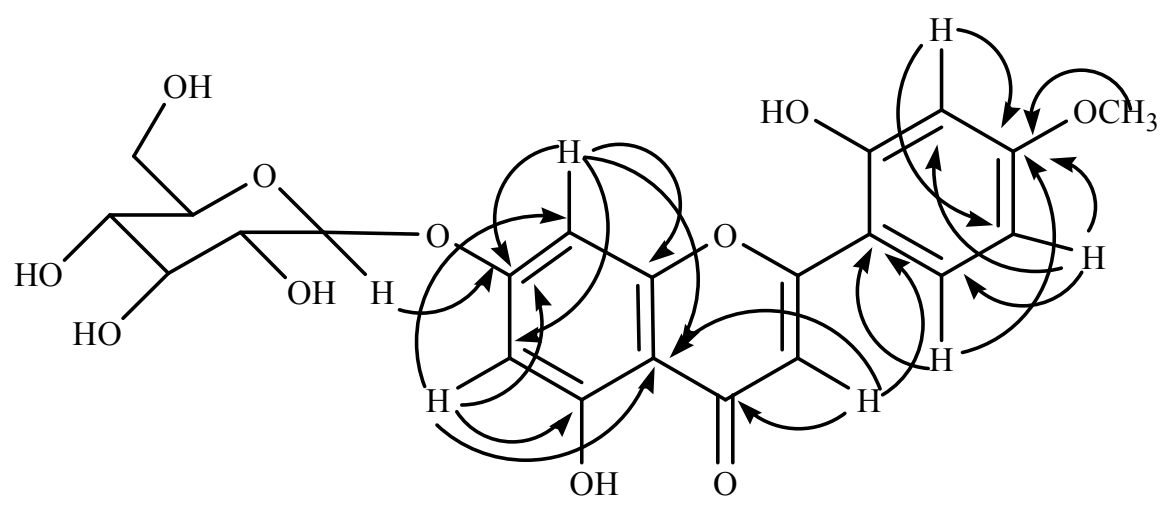




\section{Experimental Section}

\subsection{General}

Melting points were recorded on a Perfit melting point apparatus. UV spectra were measured on a Perkin-Elmer Lambda-25 spectrophotometer in methanol. IR spectra recorded on a Perkin-Elmer Spectrum RX1 FT-IR spectrometer ( $\mathrm{KBr}$ discs). NMR spectra were obtained on Bruker Avance 300 and 500 spectrometers $\left(300 \mathrm{MHz}\right.$ for ${ }^{1} \mathrm{H}$ and $125 \mathrm{MHz}$ for ${ }^{13} \mathrm{C}, \mathrm{CDCl}_{3}$ as solvent, TMS as internal standard). MS were recorded on Qualtro II-EIMS and Jeol SX-102 (FAB) mass spectrometer. Column chromatography was performed on silica gel (Merck 60-120 mesh, $15 \times 100 \mathrm{~cm}$ ). TLC was carried out on silica gel (Merck 10-40 $\mu$ ) precoated plates, spots were visualized by spraying with $7 \% \mathrm{H}_{2} \mathrm{SO}_{4}$.

\subsection{Plant material}

Aerial parts of $S$. denticulata were collected from Tungnath, Chamoli during the month of May and identified from Taxonomy Laboratory, Department of Botany, H.N.B. Garhwal University Srinagar. A voucher specimen (GUH-8036) of the plant has been kept in the Departmental Herbarium for future records.

\subsection{Extraction and isolation}

The shade dried aerial parts of $S$. denticulata $(6 \mathrm{~kg})$ were powdered and extracted exhaustively with 95\% ethanol (3 times) to yield a black brown extract, which was concentrated under reduced pressure and defatted with $n$-hexane. The extract (380 g) was pre-adsorbed with silica gel and applied on the top of a column prepared by silica gel $(500 \mathrm{~g})$ in $\mathrm{CHCl}_{3}$. The elution was first started with $\mathrm{CHCl}_{3}$ and then $\mathrm{CHCl}_{3}$ with increasing amounts of $\mathrm{MeOH}(0-30 \%)$. Elution with $\mathrm{CHCl}_{3}: \mathrm{MeOH}=22: 3$ afforded compound 1, whereas 9:1, 43:7, 41:9, 8:2 and 21:4 furnished $\beta$-sitosterol [8], 2,6-dihydroxy-4methoxyacetophenone [9], eugenol-1-O- $\beta$-D-glucopyranoside, 1-O- $\beta$-D-(3'-benzoyl)-salicyl alcohol $[10]$ and luteolin-7-O- $\beta$-D-glucopyranosyl- $(1 \rightarrow 6)$-glucopyranoside $[11,12]$, respectively.

\subsection{5-Hydroxy-2-(2-hydroxy-4-methoxyphenyl)-4-oxo-4H-chromen-7-yl $\beta$-D-glucopyranoside (1)}

Yellow amorphous solid (60 mg); m.p. 210-212 ${ }^{\circ} \mathrm{C}$ (uncorr.); UV: $\lambda_{\max }^{\mathrm{MeOH}}: 253,278$ and $353 \mathrm{~nm}$; IR: $\underset{\max }{\mathrm{KBr}}: 3373,2907,1703,1293 \mathrm{~cm}^{-1}$; NMR data: see Table 1; FAB-MS (m/z): $462[\mathrm{M}]^{+}$, $300[\mathrm{M}-\mathrm{glu}]^{+} 149\left[\mathrm{C}_{9} \mathrm{H}_{9} \mathrm{O}_{2}\right]^{+}$; calcd. C 57.14, H 4.80; found C 57.86, H 4.37. 
Table 1. ${ }^{13} \mathrm{C},{ }^{1} \mathrm{H}-\mathrm{NMR}$, HSQC and HMBC data of compound $\mathbf{1}$ in $\mathrm{CDCl}_{3}$.

\begin{tabular}{|c|c|c|c|c|}
\hline Position & $\delta_{\mathrm{C}} \mathbf{p p m}$ & $\delta_{\mathrm{H}} \mathrm{ppm}(J \mathrm{~Hz})$ & HSQC & HMBC \\
\hline 2 & 161.16 & - & $-\mathrm{C}-$ & - \\
\hline 3 & 103.20 & $6.79, \mathrm{~s}$ & $-\mathrm{CH}-$ & $4,4 a, 1$ \\
\hline 4 & 181.93 & - & $-\mathrm{C}-$ & - \\
\hline $4 a$ & 105.37 & - & $-\mathrm{C}-$ & - \\
\hline 5 & 164.50 & - & $-\mathrm{C}-$ & - \\
\hline 6 & 99.57 & $6.46(\mathrm{~d}, 1.8)$ & $-\mathrm{CH}-$ & $4 a, 5,7,8$ \\
\hline 7 & 162.98 & - & $-\mathrm{C}-$ & - \\
\hline 8 & 97.76 & $6.76(\mathrm{~d}, 1.8)$ & $-\mathrm{CH}-$ & $6,7,4 a, 8 a$ \\
\hline $8 \mathrm{a}$ & 156.98 & - & $-\mathrm{C}-$ & - \\
\hline 1 ' & 121.42 & - & $-\mathrm{C}-$ & - \\
\hline $2^{\prime}$ & 149.95 & - & $-\mathrm{C}-$ & - \\
\hline $3^{\prime}$ & 113.59 & $7.12(\mathrm{~d}, 3.4)$ & $-\mathrm{CH}-$ & $4^{\prime}, 5^{\prime}$ \\
\hline $4^{\prime}$ & 145.81 & - & $-\mathrm{C}-$ & - \\
\hline 5 & 116.02 & $7.44(\mathrm{dd}, 3.4,8.4)$ & $-\mathrm{CH}-$ & $1^{\prime}, 3^{\prime}, 4^{\prime}, 6^{\prime}$ \\
\hline $6^{\prime}$ & 119.21 & $6.92(\mathrm{~d}, 8.4)$ & $-\mathrm{CH}-$ & $1^{\prime}, 2^{\prime}, 4^{\prime}, 5^{\prime}$ \\
\hline $1 "$ & 99.92 & $5.09(\mathrm{~d}, 7.2)$ & $-\mathrm{CH}-$ & 7 \\
\hline $2 "$ & 70.36 & $3.29(\mathrm{~d}, 8.8)$ & $-\mathrm{C}-$ & - \\
\hline $3 "$ & 73.15 & $3.34(\mathrm{t}, 8.8)$ & $-\mathrm{CH}-$ & - \\
\hline $4 "$ & 76.42 & $3.32, \mathrm{~m}$ & $-\mathrm{CH}-$ & - \\
\hline $5 "$ & 77.19 & $3.49, \mathrm{~m}$ & $-\mathrm{CH}-$ & - \\
\hline $6 "$ & 60.65 & $3.73, \mathrm{~m}$ & $-\mathrm{CH}_{2}-$ & - \\
\hline $\mathrm{OCH}_{3}-4$ & 55.82 & $3.61, \mathrm{~s}$ & $-\mathrm{CH}_{3}$ & $4^{\prime}$ \\
\hline $\mathrm{OH}-5$ & - & 12.9 & - & - \\
\hline $\mathrm{OH}-2$ ' & - & 9.5 & - & - \\
\hline
\end{tabular}

\section{Acknowledgements}

The authors pay their sincere thanks to D.S.T. New Delhi, for financial assistance and R.D. Gaur, Department of Botany, Garhwal University Srinagar, for identification of the plant material.

\section{References and Notes}

1. Gaur, R.D. Flora of Garhwal North West Himalaya. Trans Media: Srinagar Garhwal, India, 1999; p. 186.

2. Zheng, S.; Wang, J.; Lu, J.; Shen, T.; Sun, L.; Shen, X. Two new acyclic diterpene- $\gamma$-lactones from Salix matsudan. Planta Med. 2000, 66, 487-489.

3. Hsu, F.L.; Nonaka, G.I.; Nishioka, I. Acylated flavanols and procyanidins from Salix sieboldiana. Phytochemistry 1985, 24, 2089-2091.

4. Lee, H.; Watanabe, N.; Sasaya, T.; Ozawa, S. Extractives of short-rotation hardwood species. I. Phenolics of the wood of Salix sachalinensis Fr. Schm. Mokuzai Gakkaishi 1993, 39, 1409-1414. 
5. Shelyuto, V.L.; Bondarenko, V.G. Flavonoids of Salix acutifolia. Khim. Prir. Soedin. 1985, 4, 567-568.

6. Kompantsev, V.A. Polyphenols of the leaves of Salix pantosericea and Salix pentandroides. Khim. Prir. Soedin. 1980, 5, 654-656.

7. Shao, Y.; Lahloub, M. F.; Meier, B.; Sticher, O. Isolation of phenolic compounds from the bark of Salix pentandra. Planta Med. 1989, 55, 617-620.

8. Sati, O.P.; Pant, G. Steroidal constituents of Agave cantala Roxb. (Rootstaks). Pharmazie 1983, 38,353 .

9. Hikino, H.; Konno, C.; Takemoto, T. Structure of pleoside from Pleopeltis thunbergiana. Yakugaku Zasshi 1969, 89, 372-374.

10. Mizuno, M.; Kato, M.; Misu, C.; Iinuma, M.; Tanaka, T. Chaenomeloidin: A phenolic glucoside from leaves of Salix chaenomeloides. J. Nat. Prod. 1991, 54, 1447-1450.

11. Montoro, P.; Braca, A.; Pizza, C.; De Tommasi, N. Structure antioxidant activity relationships of flavonoids isolated from different plant species. Food Chem. 2005, 92, 349-355.

12. Chiruvella, K. K.; Mohammed, A.; Dampuri, G.; Ghanta, R. G., Raghavan S. C. Phytochemical and antimicrobial studies of methyl angolensate and luteolin-7-O-glucoside isolated from callus cultures of Soymida febrifuga. Int. J. Biomed. Sci. 2007, 3, 269-278.

(C) 2009 by the authors; licensee Molecular Diversity Preservation International, Basel, Switzerland. This article is an open-access article distributed under the terms and conditions of the Creative Commons Attribution license (http://creativecommons.org/licenses/by/3.0/). 